\title{
Interaction of legionella pneumophila and helicobacter pylori with bacterial species isolated from drinking water biofilms
}

\author{
Maria S Gião ${ }^{1,2^{*}}$, Nuno F Azevedo ${ }^{1,2,3}$, Sandra A Wilks' ${ }^{1}$, Maria J Vieira ${ }^{2}$, Charles W Keevil ${ }^{1}$
}

\begin{abstract}
Background: It is well established that Legionella pneumophila is a waterborne pathogen; by contrast, the mode of Helicobacter pylori transmission remains unknown but water seems to play an important role. This work aims to study the influence of five microorganisms isolated from drinking water biofilms on the survival and integration of both of these pathogens into biofilms.

Results: Firstly, both pathogens were studied for auto- and co-aggregation with the species isolated from drinking water; subsequently the formation of mono and dual-species biofilms by L. pneumophila or H. pylori with the same microorganisms was investigated. Neither auto- nor co-aggregation was observed between the microorganisms tested. For biofilm studies, sessile cells were quantified in terms of total cells by SYTO 9 staining, viable $L$. pneumophila or $\mathrm{H}$. pylori cells were quantified using $16 \mathrm{~S}$ rRNA-specific peptide nucleic acid (PNA) probes and cultivable cells by standard culture techniques. Acidovorax sp. and Sphingomonas sp. appeared to have an antagonistic effect on L. pneumophila cultivability but not on the viability (as assessed by rRNA content using the PNA probe), possibly leading to the formation of viable but noncultivable (VBNC) cells, whereas Mycobacterium chelonae increased the cultivability of this pathogen. The results obtained for H. pylori showed that M. chelonae and Sphingomonas sp. help this pathogen to maintain cultivability for at least 24 hours.

Conclusions: It appears that M. chelonae may have an important role in the survival of both pathogens in drinking water. This work also suggests that the presence of some microorganisms can decrease the cultivability of $L$. pneumophila but not the viability which indicates that the presence of autochthonous microorganisms can lead to misleading results when the safety of water is assessed by cultivable methods alone.
\end{abstract}

\section{Background}

In natural environments, bacteria can adhere to surfaces forming a complex structure called a biofilm. When embedded in biofilms, microorganisms can be protected from several adverse factors such as temperature, low nutrients and the presence of biocides [1-6]. Therefore, understanding the ecology of microorganisms in this structure is fundamental in order to obtain a comprehensive knowledge of real systems. In nature, biofilms typically consist of many species of microorganisms that can interact with each other either positively (for instance, the synthesis of a metabolite by one species

\footnotetext{
* Correspondence: m.s.giao@soton.ac.uk

'School of Biological Sciences, Life Sciences Building, Highfield Campus,

University of Southampton, Southampton SO17 1BJ, UK

Full list of author information is available at the end of the article
}

which can be used in the metabolism of another) or negatively (such as nutrient competition) [7-9]. One type of biofilm that has been widely studied is that formed in drinking water distribution systems (DWDS) because of its role in the persistence of pathogens in drinking water and the consequent potential for impact on public health [10-12].

Legionella pneumophila is a waterborne pathogen that can cause Legionnaires' disease or Pontiac fever [13,14]. This pathogen is found naturally in fresh water reservoirs and can contaminate drinking water when disinfection is inefficient, being transmitted to man when contaminated aerosols are inhaled [12,15-17]. The mode of transmission of Helicobacter pylori remains controversial but drinking water as a route of transmission has recently gained recognition [18]. Although no cultivable
C Biomed Central

() 2011 Gião et al; licensee BioMed Central Ltd. This is an Open Access article distributed under the terms of the Creative Commons Attribution License (http://creativecommons.org/licenses/by/2.0), which permits unrestricted use, distribution, and reproduction in any medium, provided the original work is properly cited. 
H. pylori have ever been recovered from drinking water systems, molecular techniques such as PCR [19-22] and peptide nucleic acid (PNA) probes used to target $16 \mathrm{~S}$ rRNA in fluorescence in situ hybridization (FISH) assays $[23,24]$, have demonstrated the presence of this pathogen in DWDS. This identification, in addition to epidemiological studies, point to different prevalence of $H$. pylori in the microbial population which is associated with the type of source water. This strongly supports water as a route of transmission [18,25-27].

Previous studies have demonstrated that both pathogens can be incorporated into heterotrophic drinking water biofilms and persist for at least 32 days [28,29]. In the case of $H$. pylori, although no cultivable cells were ever recovered, the presence of a high intracellular rRNA content indicates that cells might be in a viable but non cultivable (VBNC) state $[28,30]$. It is possible that the loss of $H$. pylori cultivability when associated with heterotrophic biofilms had been due to a negative effect caused by the presence of other microorganisms [31]. Nevertheless, it is also possible that there were other microorganisms present in the biofilm that could have a beneficial effect on L. pneumophila or H. pylori, as shown by other studies where these pathogens were co-cultured with other microorganisms in liquid media $[32,33]$. However, for multi-species biofilms it is technically very challenging to determine which sessile microorganisms could have a positive or negative effect on these pathogens, particularly regarding the intimate associations that occur within biofilms. A particular type of interaction that can facilitate the formation of biofilm is the aggregation of cells, which can occur between cells of the same species (auto-aggregation) or between different species (co-aggregation), and has been well described for isolates of dental plaque species in complex media and aquatic species in potable water [34-36].

The aim of this work was to study the influence of different autochthonous microorganisms isolated from drinking water biofilms on the incorporation and survival of L. pneumophila and H. pylori in biofilms. For that, the first part of the work tested all the species used for auto and co-aggregation. Subsequently, dual-species biofilms of L. pneumophila and H. pylori were formed with the different drinking water bacteria and the results compared with mono-species biofilms formed by $L$. pneumophila and $H$. pylori.

\section{Results}

Auto and co-aggregation of L. pneumophila and other drinking water bacteria

Initially, the selected biofilm strains were tested for auto- and co-aggregation in test tubes as described by Rickard et al. [35], either alone or with L. pneumophila. No co-aggregation was observed for the strains studied, either alone or in pairs with L. pneumophila (results not shown).

\section{L. pneumophila in biofilms}

For the experiments on biofilm formation on uPVC coupons, an inoculum of L. pneumophila was prepared containing approximately $3.7 \times 10^{7}$ of total cells $\mathrm{ml}^{-1}$ (quantified using SYTO 9 staining). In comparison to total cells, 49\% were cultivable on BCYE agar and 50\% were detected by PNA-FISH. The inocula of the strains isolated from drinking water biofilms had on average $75 \%$ of cultivable cells compared to SYTO 9 stained cells, except in the case of Mycobacterium chelonae where the percentage was considerably lower (2.5\%).

Figure 1a shows the variation with time of total cells, PNA-cells and cultivable L. pneumophila present in a mono-species biofilm. The attachment of L. pneumophila cells to the surface occurred in the first 24 hours of the experiment. Moreover, the numbers of total cells (stained by SYTO 9) and PNA stained cells did not change significantly between days 1 and $32(\mathrm{P}>0.05)$. In contrast, the number of cultivable cells greatly increased in the first two weeks and then decreased significantly in the last weeks of the experiments $(\mathrm{P}<$ 0.05).

For the experiments of L. pneumophila in dual-species it was observed that the numbers of L. pneumophila PNA-positive cells and cultivable L. pneumophila did not change significantly with time after the first day ( $P$ $>0.05)$. Table 1 presents the data obtained for the quantification of sessile cells, giving the average values of the samples analyzed at all time points, for mono and dualspecies biofilms. The data for the numbers of total cells, total PNA-positive L. pneumophila and cultivable $L$. pneumophila in mono and in dual species biofilms were similar ( $\mathrm{P}>0.95$ ), except for the numbers of cultivable L. pneumophila when associated with Acidovorax sp. which were significantly lower $(\mathrm{P}<0.05)$. Figure $1 \mathrm{~b}$ shows the percentage of PNA-positive L. pneumophila in relation to SYTO 9 stained total cells; this was similar for both mono and dual-species biofilms $(\mathrm{P}=1.000)$. This indicates that L. pneumophila adhere well to uPVC surfaces, either alone or in the presence of Variovorax paradoxus, M. chelonae, Acidovorax sp. And Sphingomonas sp., although the morphology of the biofilm appeared to be different for the mono or dual-species (Figure $2 \mathrm{a}$ and $2 \mathrm{~b}$, respectively). The relationship between cultivable and L. pneumophila PNA-positive cells was higher (although not statistically significant, $\mathrm{P}$ $>0.95$ ) for cells recovered from the L. pneumophila $M$. chelonae biofilm while the numbers of cultivable $L$. pneumophila decreased five-fold when this pathogen was associated with Acidovorax sp. and almost four-fold when associated with Sphingomonas sp. 


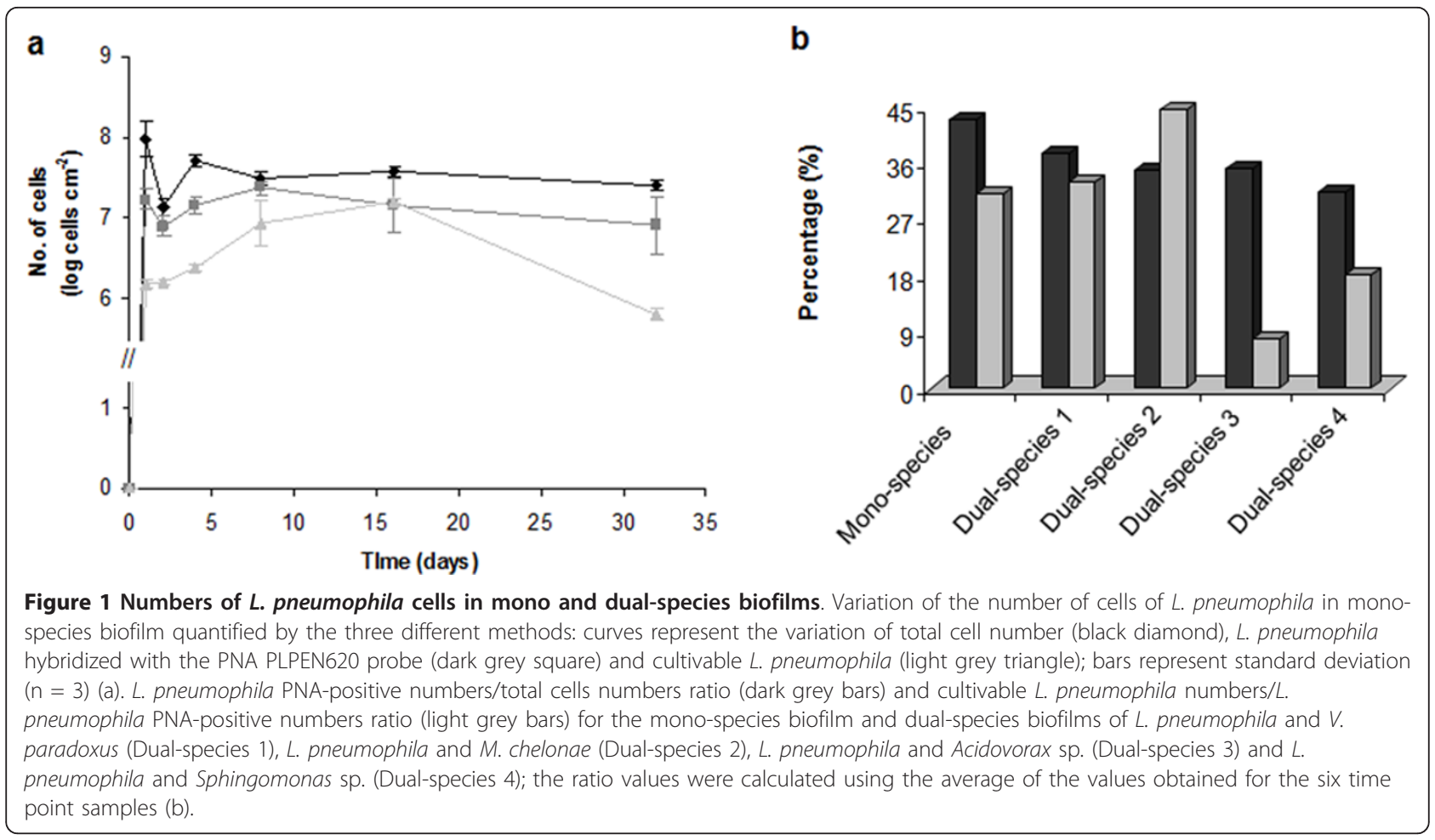

Auto and co-aggregation of $H$. pylori and other drinking water bacteria

The same experiments were repeated using $H$. pylori instead of L. pneumophila. For the auto- and co-aggregation of $H$. pylori with drinking water isolates, the same strains were used as selected for the L. pneumophila experiments and an additional strain was also included: Brevundimonas sp., a bacterium isolated on CBA medium from drinking water biofilms. The results obtained in the test tube assay system showed neither auto nor co-aggregation of $H$. pylori with any of the species investigated.

\section{H. pylori in biofilms}

The biofilm experiments used the same strains indicated in the previous paragraph. It was observed that for the $H$. pylori inoculum, only $5 \%$ of the total cells were cultivable, a value similar to that obtained by Azevedo et al. [37], while $29 \%$ were detected by PNA-FISH. Figure $3 \mathrm{a}$ and $3 \mathrm{~b}$ show that $H$. pylori is able to form biofilms, despite the poor cultivability of the cells on agar media. However, while the morphology of $H$. pylori cells from the inoculum was predominantly spiral, after forming biofilms the cells were mainly coccoid shaped.

Figure 3c shows that when in pure culture $H$. pylori adhered to the surface to form the biofilm in the first day followed by a statistically significant decrease $(\mathrm{P}<$ 0.05 ) in total cells during day 1 and 4 . The same trend was observed for cells quantified using the PNA probe. No cultivable $H$. pylori were recovered on CBA medium. When the biofilm was formed in the presence of Brevundimonas sp. the variation with time of total cells and PNA numbers were not statistically significant $(\mathrm{P}>$ 0.05). Comparing the numbers obtained for pure $H$.

Table 1 Average of the total number of cells, L. pneumophila PNA-positive, cultivable L. pneumophila and cultivable non-legionellae cell numbers in mono and dual-species biofilms obtained for all the time points sampled.

\begin{tabular}{|c|c|c|c|c|}
\hline Strain in biofilm & $\begin{array}{l}\text { Total cells } \times 10^{-7} \\
\left(\text { cells } \mathrm{cm}^{-2} \text { ) }\right.\end{array}$ & $\begin{array}{l}\text { PNA cells } \times 10^{-7} \\
\left(\text { cells } \mathrm{cm}^{-2}\right)\end{array}$ & $\begin{array}{l}\text { Cultivable L. pneumophila } \times 10^{-6} \\
\left(\text { CFU cm}{ }^{-2} \text { ) }\right.\end{array}$ & $\begin{array}{l}\text { Cultivable non - legionellae } \times 10^{-6} \\
\left(\text { (CFU } \mathrm{cm}^{-2}\right)\end{array}$ \\
\hline L. pneumophila & 4.42 & 1.48 & 5.25 & n.a. \\
\hline $\begin{array}{l}\text { L. pneumophila and } V \text {. } \\
\text { paradoxus }\end{array}$ & 3.51 & 1.11 & 4.11 & 4.49 \\
\hline M. chelonae & 4.87 & 1.05 & 4.65 & 0.19 \\
\hline Acidovorax sp. & 4.12 & 1.59 & 1.05 & 6.55 \\
\hline Sphingomonas sp. & 3.80 & 0.83 & 1.45 & 1.06 \\
\hline
\end{tabular}

n.a. - not applicable. 

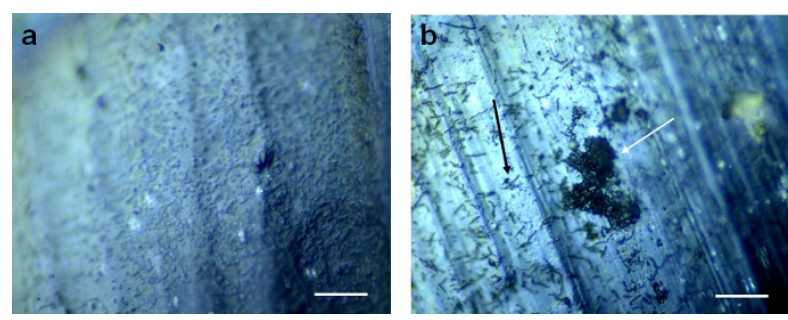

Figure 2 uPVC coupon covered with a mono and dual-species L. pneumophila biofilm. Microphotograph of an UPVC coupon visualized under EDIC microscopy covered with a 32 days-old biofilm formed by L. pneumophila (a) and L. pneumophila and Sphingomonas sp. (b). The black arrow indicates individual cells attached to the UPVC surface and white arrow indicates a microcolony. Bars represent $20 \mu \mathrm{m}$.

pylori biofilms and biofilms grown in the presence of Brevundimonas sp. there was no significant difference between the numbers of $H$. pylori detected using the PNA probe (results not shown) nor in the percentage between PNA and total cells numbers $(\mathrm{P}>0.05)$.

In terms of cultivable cells it was observed that no cultivable $H$. pylori were ever recovered from any of the mono or dual-species biofilms at any time point, with the exception of cells recovered from 1 day-old biofilms grown in the presence of $M$. chelonae or Sphingomonas sp. $\left(6.67 \times 10^{1}\right.$ and $1.83 \times 10^{2} \mathrm{CFU} \mathrm{cm}^{-2}$, respectively).

\section{Discussion}

Auto and co-aggregation of L. pneumophila and $H$. pylori with drinking water bacteria

In a previous study several bacterial strains were isolated from heterotrophic biofilms formed on uPVC coupons in a two-stage chemostat system [28]. For the present work, the selection of the bacteria used was based on the prevalence of these isolated strains in biofilms, i.e., the strains that were always present in biofilm samples when detected by culture were used rather than those only found intermittently.

In the aggregation studies it was observed that there was no auto-aggregation of any of the bacteria tested in this study, as demonstrated previously for Brevundimonas vesicularis, Acidovorax delafieldii and $V$. paradoxus $[34,38]$. No co-aggregation of L. pneumophila or $H$. pylori was observed with any of the bacteria isolated from drinking water biofilms, demonstrating that while all of the bacteria used in this study have the ability to form biofilms they are attaching to the uPVC surfaces without aggregating in the planktonic phase with the other microorganisms [36].

\section{L. pneumophila in biofilms}

The L. pneumophila cells from the inocula prepared for the biofilm experiments were quantified for total, PNA- positive and cultivable cells. Results showed that cultivable and PNA numbers were similar but were only $50 \%$ of the numbers obtained by SYTO 9 staining. It is still controversial whether PNA probes detect dead cells or if they just produce a detectable signal with viable cells. PNA probes have been used to detect pathogens in mixed biofilms but it has not been well established if this technique can also detect non-viable cells $[23,29,39]$. However the similarity in the cultivable and PNA-positive numbers, and the difference between PNA-labelled and total cells (stained by SYTO 9), strongly indicates that the PNA probe fails to detect dead cells. PNA probes bind specifically to rRNA molecules emitting a signal that can be visualized under microscopy. The intensity of that signal is related to the rRNA content, i.e., the higher the rRNA content the brighter the signal is [40]. A very low content of rRNA would result in insufficient brightness and cells would not be visualized. After cellular death the content of rRNA decreases significantly and therefore some authors have suggested that the emission of a bright signal is a good indication of cell viability [39,41,42]. The results obtained in the present study (Figure 1a) support that there is a correlation between the number of viable cells and the number of cells that bind to the PNA probe but further studies should be performed to correlate the PNA-positive cells and their metabolic state.

As it has been demonstrated before by other authors $[43,44]$, the attachment of L. pneumophila cells to the uPVC surface occurred on the first day of biofilm formation and the numbers of total and PNA stained cells, from mono-species biofilms, did not change significantly $(P>0.05)$. Nevertheless, the numbers of cultivable cells increased in the first two weeks and decreased during the rest of the experiment. It has been demonstrated that L. pneumophila can survive in tap water for long periods without losing cultivability $[45,46]$, but is not able to replicate in axenic cultures in tap water or in low nutrient media, except when associated with biofilms or parasitizing amoebal species $[29,47,48]$. After two weeks the cultivability decreased but was not completely lost for the 32 days of the experiment which indicates that biofilms are a protective niche for $L$. pneumophila, even in axenic culture. Conversely, PNApositive numbers with a high fluorescence intensity remained constant and, for the same reason explained before, this suggests that cells are still viable. Moreover, the fact that total L. pneumophila and L. pneumophila PNA-positive cells remained constant with time indicates that there is no damage to DNA and rRNA, respectively. Conversely, the variation of PNA-positive numbers in dual-species biofilms was used as an indicator of the variation of viable L. pneumophila cells inside of those biofilms. 

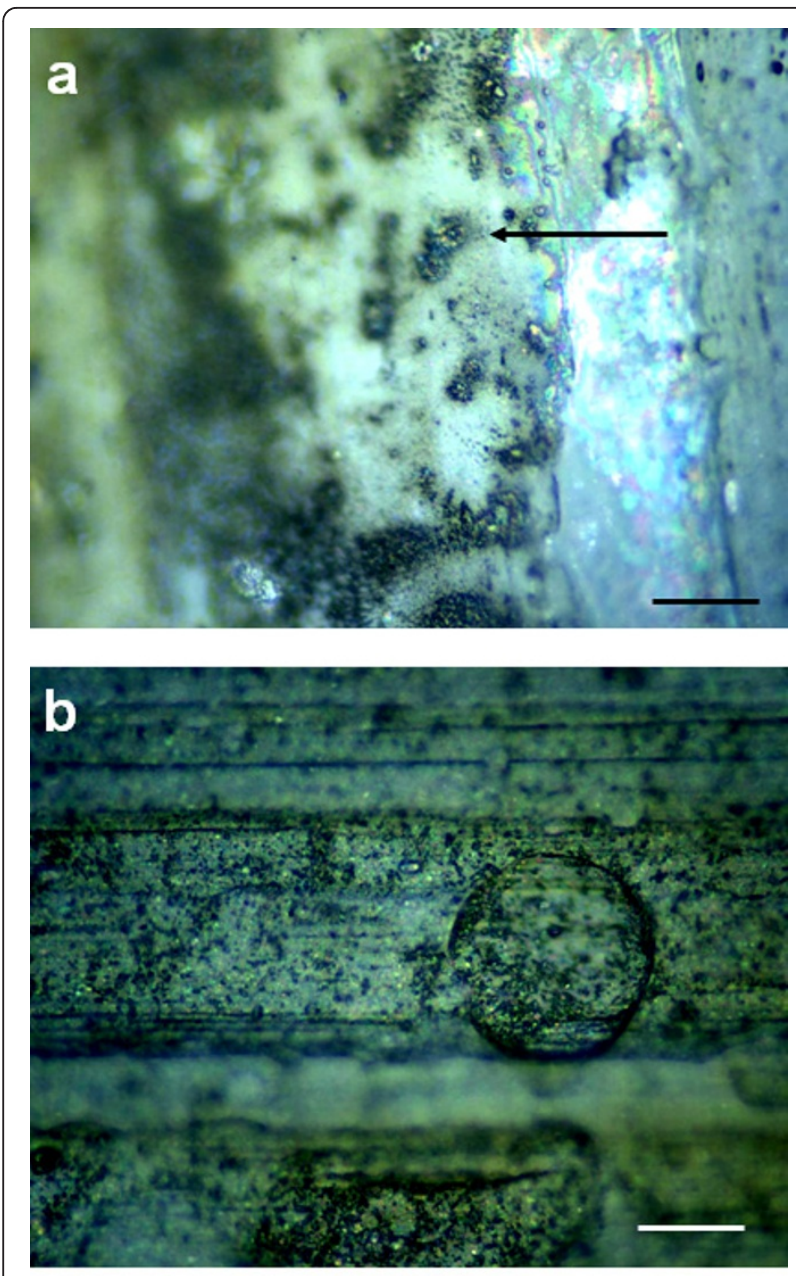

C

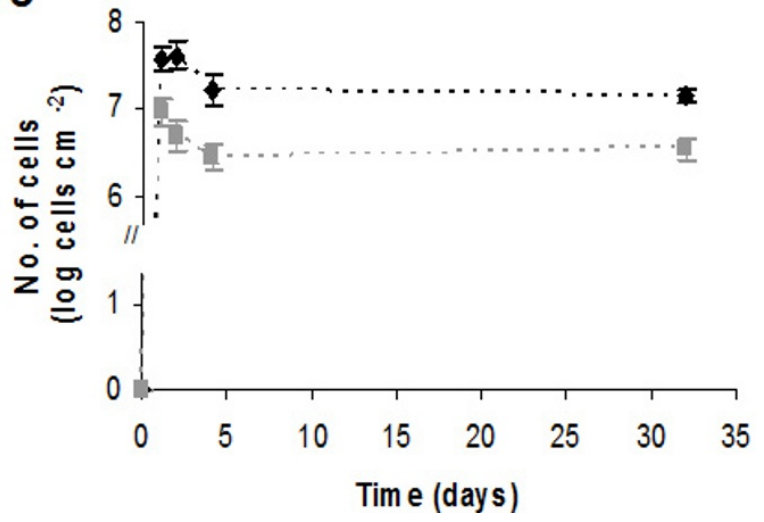

Figure 3 uPVC coupon covered with $H$. pylori biofilm and variation of $H$. pylori numbers in the mono-species biofilm Microphotograph of an UPVC coupon visualized under EDIC microscopy covered with a mono-species $H$. pylori biofilm after 1 day (a) and 32 days (b) of incubation. Black arrow indicates the presence of a microcolony. Bars represent $20 \mu \mathrm{m}$. (c) Variation with time in the total cell number (black diamond) and H. pylori PNAcells (grey square) present in the biofilm. Bars represent standard deviation $(n=3)$.
The results of dual-species biofilms showed that when biofilms were formed in the presence of $M$. chelonae the percentage of cultivable L. pneumophila in relation to $L$. pneumophila PNA-positive cells was slightly superior compared to mono-species biofilms or dual-species biofilms with the other strains isolated from drinking water. Although the difference is not statistically significant this result indicates that this strain has a small positive effect on L. pneumophila cultivability. In contrast, the numbers of cultivable L. pneumophila decreased when this pathogen was associated with Acidovorax sp. indicating that this species has a negative impact on L. pneumophila cultivability. It was also observed that the numbers of cultivable L. pneumophila when co-cultivated with Sphingomonas sp. decreased and, although the statistical analysis showed that the difference is not significant, the fact that the cultivability was almost four-fold lower appears to reveal an antagonistic effect. Conversely, it appears that both strains affect negatively sessile L. pneumophila cultivability, either by competition for nutrients or production of a metabolite toxic to L. pneumophila. The fact that these two species were isolated on $\mathrm{R} 2 \mathrm{~A}$ reveals that they have low nutritional requirements to grow and might even be able to grow in water, contrary to L. pneumophila which is not able to grow in absence of, for example, Lcysteine and high iron concentrations $[49,50]$. This is corroborated by the values shown in Table 1, where cultivable Acidovorax sp. and Sphingomonas sp. numbers

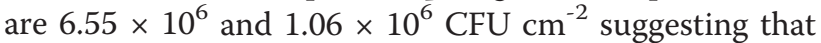
these two microorganisms could be metabolically active in the biofilm despite the poor nutrient concentration of the medium (filtered tap water). Another possible explanation for the lower numbers of cultivable L. pneumophila when biofilms were formed in co-culture with Sphingomonas sp., can be related to the structure of the biofilm. Figure 2 shows a 32 days-old biofilm formed by L. pneumophila and L. pneumophila associated with Sphingomonas sp. The biofilm formed in the presence of Sphingomonas sp. had a different morphology, and although the thickness of the biofilm has not been measured, the presence of microcolonies suggests the presence of thicker structures where anaerobic zones might occur. Wadowsky et al. [33] have demonstrated that in anaerobic conditions L. pneumophila loses cultivability and if biofilms formed by L. pneumophila and Sphingomonas sp. have indeed anaerobic zones, then it is possible that L. pneumophila located in those places has become uncultivable. It would therefore be interesting to undertake further research to measure the thickness of different parts of the biofilm and the respective concentration of oxygen and relate those results to the cultivability of cells from those regions. However, the fact that the numbers quantified by the use of a PNA probe 
remained constant, might indicate that these cells may still be viable and can probably recover cultivability in favorable conditions.

This work clearly demonstrates that L. pneumophila can be negatively or positively influenced by other microorganisms present in drinking water. It is important to note that this study was carried out under particular conditions and it will be important to perform more experiments in the future, in particular to study the effect of other drinking water bacteria, the formation of biofilms under dynamic conditions and the incorporation of a disinfectant, such as chlorine.

It is known that other bacteria can influence the growth of L. pneumophila either in nutrient-poor environments, such as drinking water, or in rich artificial media. Toze et al. [51] have demonstrated that some bacteria commonly present in heterotrophic biofilms, such as Pseudomonas sp. and Aeromonas sp., can inhibit the growth of L. pneumophila while Wadowsky and Yee [49] demonstrated that Flavobacterium breve can support the satellite growth of this pathogen on BCYE agar without L-cysteine. A curious result was obtained by Temmerman et al. [52] who demonstrated that dead cells can also support the growth of this pathogen. Although the mechanisms responsible for the influence of different microorganisms on L. pneumophila survival are unknown there is one aspect of $L$. pneumophila microbial ecology that has been already well-established: L. pneumophila is not able to grow in drinking water unless associated with biofilms or amoebal species $[46,47,53]$. Hence, the knowledge of how microorganisms affect $L$. pneumophila cultivability is a key factor for the effective control of this pathogen in drinking water and associated biofilms, and requires further investigation.

\section{H. pylori in biofilms}

In this study the cells recovered from mono-species $H$. pylori biofilms were always uncultivable, for all the time points, which is in contrast to the Azevedo et al. [54] study, where it was demonstrated that after 24 hours sessile $H$. pylori cells were still cultivable. This might be due to the differences in the method of cell removal from the coupons, the quality of water or the type of uPVC substratum. When the biofilm was formed in the presence of Brevundimonas sp. no cultivable $H$. pylori cells were ever recovered either. However, for this case, care should be taken in the interpretation of the results. In fact, Brevundimonas was able to grow on CBA medium in a faster and more abundant way then $H$. pylori. As such, it is impossible to determine whether $H$. pylori is indeed uncultivable in the presence of this microorganism, or whether it could not be detected because it was overgrown by Brevundimonas. We have attempted to solve this issue by using CBA medium supplemented with antibiotics but, as shown by other authors [28], available selective medium for $H$. pylori allows the growth of other species, including Brevundimonas sp. The fact that there were no differences in the results for the PNA-positive cell numbers obtained for $H$. pylori in mono-species biofilms and in dual-species biofilms with Brevundimonas sp. suggests that this bacterium has little or no effect on the inclusion of $H$. pylori in biofilms.

Cultivable H. pylori was never recovered from dualspecies biofilms at any time point, independently of the second species used, except when $H$. pylori formed dual-species biofilms in the presence of $M$. chelonae and Sphingomonas sp. For these two microorganisms, it was observed that $H$. pylori was able to retain cultivability for a period of between 24 and 48 hours. This suggests that both microorganisms might have a positive effect on the inclusion and survival of this pathogen in drinking water biofilms. The ability of $H$. pylori to adapt to different physico-chemical parameters has been studied by several authors [30,55-58], however no studies about the influence of other microorganisms on the survival of this pathogen have been found in the literature except the coculture of $H$. pylori with the protozoan, Acanthamoeba castellanii [59]. The interaction of microorganisms in biofilms has been widely studied and in this particular case could be the key for the survival of this microorganism in drinking water systems, even if in a VBNC state. More investigations should therefore be performed concerned with the influence of drinking water microorganisms on $H$. pylori metabolism and survival.

\section{Conclusions}

This work clearly demonstrates that, even in pure culture, both pathogens can adhere to surfaces and form biofilm. L. pneumophila can remain cultivable for at least 32 days although less cultivable when associated with Acidovorax sp. and Sphingomonas sp. The experiments with $H$. pylori demonstrated that this pathogen loses cultivability in less than 24 hours when in monospecies or in dual-species biofilms with $V$. paradoxus, Acidovorax sp. and Brevundimonas sp., while retaining cultivability for at least 24 hours when biofilms are grown in the presence of M. chelonae and Sphingomonas sp. Consequently, M. chelonae seems to have a positive effect on the cultivability of both pathogens and being a pathogen commonly found in drinking water systems $[60,61]$, can play an important role in the control of these two pathogens. Control of this mycobacterial opportunistic pathogen and other biofilm species that can have a synergetic effect on $L$. pneumophila and $H$. pylori might provide an important contribution towards the supply of safe drinking water as both $L$. 
pneumophila and $H$. pylori have been found to be chlorine resistant $[62,63]$.

\section{Methods}

\section{Culture maintenance}

In this work, L. pneumophila NCTC 12821 and $H$. pylori NCTC 11637 strains were used. Strains of $V$. paradoxus, M. chelonae, Acidovorax sp., Sphingomonas sp. and Brevundimonas sp. were isolated from drinking water biofilms $[28,29]$. All strains were maintained in vials frozen at $-80^{\circ} \mathrm{C}$ and recovered by standard plating procedures onto the appropriate media and subcultured once prior to biofilm formation experiments. L. pneumophila NCTC 12821, V. paradoxus and M. chelonae were grown on Buffered Charcoal Yeast Extract (BCYE) agar (Oxoid, UK) for 24 hours at $30^{\circ} \mathrm{C}$. Acidovorax sp. and Sphingomonas sp. were grown on R2A (Oxoid, UK) for 48 hours at $22^{\circ} \mathrm{C}$. H. pylori NCTC 11637 and Brevundimonas sp. were grown on Columbia Agar (Oxoid, UK) supplemented with $5 \%(\mathrm{v} / \mathrm{v})$ defibrinated horse blood (CBA) (Oxoid, UK) and incubated for 48 hours at $37^{\circ} \mathrm{C}$ in a microaerophilic atmosphere of $10 \% \mathrm{CO}_{2}, 7 \% \mathrm{H}_{2}$ and $3 \% \mathrm{O}_{2}$ (the remainder being $\mathrm{N}_{2}$ ).

\section{Auto- and co-aggregation in test tubes}

Prior to the start of the experiments tap water from Southampton, UK, was collected in a transparent flask and left, loosely closed, overnight for chlorine evaporation. Then the water was sterilized by filtration through a $0.2 \mu \mathrm{m}$ pore size Nylon filter (Pall Gelman, UK). All bacterial species were suspended in this dechlorinated and filtered tap water, with the following characteristics, provided by the water company (Southern Water, UK): pH 7.3; turbidity $0.10 \mathrm{FTU}$; conductivity $504 \mu \mathrm{S} \mathrm{cm}^{-1}$; total organic carbon $0.649 \mathrm{mg} \mathrm{l}^{-1}$; total iron $16 \mu \mathrm{g} \mathrm{Fe}^{-1}$; free chlorine $0.21 \mathrm{mg} \mathrm{Cl}_{2} \mathrm{l}^{-1}$; total chlorine $0.26 \mathrm{mg} \mathrm{Cl}_{2}$ $\mathrm{l}^{-1}$. The inocula had a final concentration of approxi-

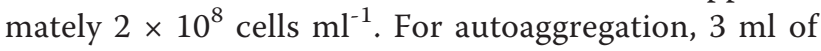
each suspension was transferred into a sterile test tube, whereas for co-aggregation experiments $1.5 \mathrm{ml}$ of either L. pneumophila or $H$. pylori suspension were mixed with $1.5 \mathrm{ml}$ of each one of the species isolated from drinking water biofilms. At times $0,1,2,4,6,8,24$ and 48 hours, tubes were vortexed for 10 seconds and observed for co-aggregation according to the scale described by Rickard et al. [35]. All experiments were performed in duplicate.

\section{Coupon preparation}

Unplasticized polyvinylchloride (uPVC) coupons of 1 $\mathrm{cm}^{2}$ were used as a substratum for biofilm growth as it is a commonly used material in drinking water pipelines. To remove grease and wax from the coupons, prior to biofilm growth, they were immersed in water and detergent for $5 \mathrm{~min}$, washed with a bottle brusher, rinsed twice in distilled water and air-dried. Subsequently, they were washed in $70 \%(\mathrm{v} / \mathrm{v})$ ethanol to remove any organic compounds and autoclaved at 1 atm and $121^{\circ} \mathrm{C}[64]$.

\section{Biofilm formation}

To form the mono-species biofilms of L. pneumophila NCTC 12821 and H. pylori NCTC 11637 the inocula were prepared by suspending the cells in $50 \mathrm{ml}$ of dechlorinated and filtered tap water to give a final concentration of approximately $10^{7}$ cells $\mathrm{ml}^{-1}$. The monospecies biofilms were used as a control. The dual-species biofilm inocula were prepared by mixing L. pneumophila or $H$. pylori with $V$. paradoxus, M. chelonae, Acidovorax sp. or Sphingomonas sp. in $50 \mathrm{ml}$ of filtersterilized tap water to a final concentration of $10^{7}$ cells $\mathrm{ml}^{-1}$ of each microorganism. For the experiments with $H$. pylori an inoculum was also prepared with this pathogen and Brevundimonas sp. All suspensions were homogenized by vortexing and $4 \mathrm{ml}$ of each inoculum were transferred to 6-well microtiter plates containing one uPVC coupon in each well. Plates were incubated in the dark at $22^{\circ} \mathrm{C}$ and two coupons of each biofilm type were removed after 1, 2, 4, 8, 16 and 32 days, and gently rinsed to remove loosely attached cells on the surface of the biofilm. One coupon was used for direct observation under a Nikon Eclipse E800 episcopic differential interference contrast/epifluorescence (EDIC/EF) microscope (Best Scientific, UK) [65] using the EDIC channel to directly visualise biofilm. The other coupon was scraped to quantify sessile cells.

\section{Quantification of sessile cells}

At each time point coupons were removed from the wells and rinsed three times in filtered tap water to remove planktonic cells from the biofilm and coupons surfaces. The coupons were then transferred to a $15 \mathrm{ml}$ centrifuge tube (Greiner Bio-one, UK) containing $2 \mathrm{ml}$ of filter-sterilized tap water and autoclaved glass beads of $2 \mathrm{~mm}$ diameter (Merck, UK). To remove the biofilm from the coupon surfaces the tubes were then vortexed for $1 \mathrm{~min}$. The vortexing step also promoted the homogenization of the suspensions prior to the quantification of total cells, PNA-positive cells and cultivable cells, as described below. Preliminary experiments showed that vortexing with glass beads removed the biofilm formed under these conditions, although it was still possible to observe a few dispersed cells on the uPVC surface.

Total cells were quantified using the SYTO 9 staining method (Molecular Probes, Invitrogen, UK). In summary, $1 \mathrm{ml}$ of an appropriate dilution was mixed with $0.5 \mu \mathrm{l}$ of SYTO 9, incubated in the dark for 15 minutes, filtered through a $0.2 \mu \mathrm{m}$ pore size polycarbonate black 
Nucleopore ${ }^{\circledR}$ membrane (Whatman, UK) and allowed to air-dry. Then a drop of non-fluorescent immersion oil (Fluka, UK) and a coverslip were added before observation under the Nikon Eclipse E800 EDIC/EF microscope (Best Scientific, UK) [65]. As the cells were homogenously distributed, 10 fields of view on each membrane were chosen at random and the number of cells counted ( $\times 100$ objective lens).

L. pneumophila was quantified using the specific PNA probe PLPNE620 (5'-CTG ACC GTC CCA GGT-3') and $H$. pylori by the use of a PNA probe with the following sequence 5'- GAGACTAAGCCCTCC -3'(Eurogentec, Belgium). PNA-FISH was carried out by filtering $1 \mathrm{ml}$ of an appropriate dilution through a $0.2 \mu \mathrm{m}$ Anodisc membrane (Whatman, UK). This was left to air dry. For the quantification of L. pneumophila the membrane was covered with $90 \%(\mathrm{v} / \mathrm{v})$ ethanol to fix the cells and again air dried. The hybridization, washing and microscopy observation method was performed as described by Wilks and Keevil [42]. For H. pylori quantification the membrane was covered with $4 \%(\mathrm{w} / \mathrm{v})$ paraformaldehyde followed by $50 \%(\mathrm{v} / \mathrm{v})$ ethanol for 10 minutes each to fix the cells and air dried. The hybridization, washing and microscopy observation method was performed as described by Guimarães et al. [66].

Cultivable numbers of all bacteria were determined by plating $40 \mu \mathrm{l}$ of an appropriate dilution on the respective agar medium, as described above in the section "Culture maintenance". BCYE plates were incubated aerobically for two days at $30^{\circ} \mathrm{C}, \mathrm{R} 2 \mathrm{~A}$ for seven days at $22^{\circ} \mathrm{C}$ and CBA plates were incubated for seven days at $37^{\circ} \mathrm{C}$ in a microaerophilic atmosphere. It is recommended that the incubation of BCYE to quantify L. pneumophila from environmental samples goes for up to ten days. However it was observed that for these samples if the BCYE plates were incubated for more than two days the colonies would overgrow in diameter and it would be impossible to distinguish individual colonies. Therefore two days was chosen as the incubation time.

\section{Statistical analysis}

The homogeneity of variances of total number, PNA and cultivable cells and the relation between L. pneumophila of cells and total cells was checked by the Levene test for equality of variances using a statistical package (SPSS Inc., Chicago IL, USA). Results were subsequently compared by a one-way ANOVA followed by a Bonferroni post hoc test. Differences were considered relevant if $\mathrm{P}<0.05$.

\section{Aknowledgements}

This work was supported by the Portuguese Institute Fundação para a Ciência e Tecnologia (PhD grant SFRH/BD/17088/2004 and post-doc grant SFRH/BPD/20484/2004).

\section{Author details}

'School of Biological Sciences, Life Sciences Building, Highfield Campus, University of Southampton, Southampton SO17 1BJ, UK. ${ }^{2}$ Institute for Biotechnology and Bioengineering, Centre of Biological Engineering, Universidade do Minho, Campus de Gualtar 4710-057, Braga, Portugal. ${ }^{3}$ LEPAE, Department of Chemical Engineering, Faculty of Engineering, University of Porto, Porto, Portugal.

\section{Authors' contributions}

MSG participated in the experimental design, carried out all experimental work and drafted the manuscript. NFA, SAW, MJV and CWK participated in the design of the study and helped to draft the manuscript. All authors have read and approved the final manuscript.

Received: 22 July 2010 Accepted: 18 March 2011

Published: 18 March 2011

\section{References}

1. Camper A, Burr M, Ellis B, Butterfield P, Abernathy C: Development and structure of drinking water biofilms and techniques for their study. J App Microbiol 1999, 85:1S-12S.

2. Costerton JW, Lewandowski Z, Caldwell DE, Korber DR, Lappin-Scott HM: Microbial biofilms. Ann Rev Microbiol 1995, 49(1):711-745.

3. Emtiazi F, Schwartz T, Marten SM, Krolla-Sidenstein P, Obst U: Investigation of natural biofilms formed during the production of drinking water from surface water embankment filtration. Water Res 2004, 38(5):1197-1206.

4. Fletcher M, Marshall KC: Are solid surfaces of ecological significance to aquatic bacteria. In Advances in microbial ecology. Volume 6. Edited by: Marshall KC. New York: Plenum Publishing Corp; 1982:199-230.

5. LeChevallier MW, Cawthon CD, Lee RG: Factors promoting survival of bacteria in chlorinated water supplies. App Environ Microbiol 1988, 54(3):649-654.

6. Ellwood DC, Keevil CW, Marsh PD, Brown CM, Wardell JN, Le Roux N: Surface-Associated Growth [and Discussion]. Philos T R Soc B 1982, 297:517-532.

7. Christensen BB, Haagensen JAJ, Heydorn A, Molin S: Metabolic commensalism and competition in a two-species microbial consortium. App Environ Microbiol 2002, 68(5):2495-2502.

8. Rao D, Webb JS, Kjelleberg S: Competitive interactions in mixed-species biofilms containing the marine bacterium Pseudoalteromonas tunicata. App Environ Microbiol 2005, 71(4):1729-1736.

9. Watnick P, Kolter R: Biofilm, city of microbes. J Bacteriol 2000, 182(10):2675-2679

10. Berry $\mathrm{D}, \mathrm{Xi} \mathrm{CW}$, Raskin L: Microbial ecology of drinking water distribution systems. Curr Opin Biotechnol 2006, 17(3):297-302.

11. Szewzyk U, Szewzyk R, Manz W, Schleifer KH: Microbiological safety of drinking water. Ann Rev Microbiol 2000, 54:81-127.

12. Keevil CW: Pathogens in environmental biofilms. In The Encyclopedia of Environmental Microbiology. Edited by: Bitton G. New York: Wiley; 2002:2339-2356.

13. McDade JE, Shepard CC, Fraser DW, Tsai TR, Redus MA, Dowdle WR Legionnaires' disease - isolation of a bacterium and demonstration of its role in other respiratory disease. New Engl J Med 1977, 297(22):1197-1203.

14. Pasculle W: Update on Legionella. Clin Microbiol Newslett 2000, 22(13):97-101.

15. Devos $\mathrm{L}$, Boon $\mathrm{N}$, Verstraete W: Legionella pneumophila in the environment: The occurrence of a fastidious bacterium in oligotrophic conditions. Rev Environ Sci Biotechnol 2005, 4(1):61-74.

16. Hsu SC, Martin R, Wentworth BB: Isolation of Legionella species from drinking water. App Environ Microbiol 1984, 48(4):830-832.

17. Steinert $\mathrm{M}$, Hentschel $\mathrm{U}$, Hacker J: Legionella pneumophila: an aquatic microbe goes astray. FEMS Microbiol Rev 2002, 26(2):149-162.

18. Azevedo NF, Guimaraes N, Figueiredo C, Keevil CW, Vieira MJ: A new model for the transmission of Helicobacter pylori: Role of environmental reservoirs as gene pools to increase strain diversity. Crit Rev Microbiol 2007, 33(3):157-169.

19. Bunn JEG, Mackay WG, Thomas JE, Reid DC, Weaver LT: Detection of Helicobacter pylori DNA in drinking water biofilms: implications for transmission in early life. Lett App Microbiol 2002, 34(6):450-454. 
20. Mackay WG, Gribbon LT, Barer MR, Reid DC: Biofilms in drinking water systems - A possible reservoir for Helicobacter pylori. Water Sci Technol 1998, 38(12):181-185.

21. Park SR, Mackay WG, Reid DC: Helicobacter sp recovered from drinking water biofilm sampled from a water distribution system. Water Res 2001, 35(6):1624-1626

22. Voytek MA, Ashen JB, Fogarty LR, Kirshtein JD, Landa ER: Detection of Helicobacter pylori and fecal indicator bacteria in five North American rivers. J Water Health 2005, 3(4):405-422.

23. Bragança SM, Azevedo NF, Simões LC, Keevil CW, Vieira MJ: Use of fluorescent in situ hybridisation for the visualisation of Helicobacter pylori in real drinking water biofilms. Water Sci Technol 2007, 55(8):387-393.

24. Queralt N, Bartolome R, Araujo R: Detection of Helicobacter pylori DNA in human faeces and water with different levels of faecal pollution in the north-east of Spain. J App Microbiol 2005, 98(4):889-895.

25. Engstrand L: Helicobacter in water and waterborne routes of transmission. J App Microbiol 2001, 90:80S-84S.

26. Gomes BC, Martinis ECP: The significance of Helicobacter pylori in water, food and environmental samples. Food Control 2004, 15(5):397-403.

27. Klein PD, Graham DY, Gaillour A, Opekun AR, Smith EO: Water source as risk factor for Helicobacter pylori infection in Peruvian children. Lancet 1991, 337(8756):1503-1506.

28. Gião MS, Azevedo NF, Wilks SA, Vieira MJ, Keevil CW: Persistence of Helicobacter pylori in heterotrophic drinking water biofilms. App Environ Microbiol 2008, 74(19):5898-5904.

29. Gião MS, Wilks SA, Azevedo NF, Vieira MJ, Keevil CW: Comparison between standard culture and peptide nucleic acid $16 \mathrm{~S}$ rRNA hybridization quantification to study the influence of physico-chemical parameters on Legionella pneumophila survival in drinking water biofilms. Biofouling 2009, 25(4):335-343.

30. Azevedo NF, Pacheco AP, Keevil CW, Vieira MJ: Nutrient shock and incubation atmosphere influence recovery of culturable Helicobacter pylori from water. App Environ Microbiol 2004, 70(1):490-493.

31. Tait K, Sutherland IW: Antagonistic interactions amongst bacteriocin producing enteric bacteria in dual species biofilms. J App Microbiol 2002, 93(2):345-352.

32. Surman SB, Morton LHG, Keevil CW: The dependence of Legionella pneumophila on other aquatic bacteria for survival on R2A medium. Int Biodeter Biodegr 1994, 13:223-236.

33. Wadowsky RM, Wolford R, McNamara AM, Yee RB: Effect of temperature, $\mathrm{pH}$, and oxygen level on the multiplication of naturally occurring Legionella pneumophila in potable water. App Environ Microbio/ 1985 49(5):1197-1205.

34. Buswell CM, Herlihy YM, Marsh PD, Keevil CW, Leach SA: Coaggregation amongst aquatic biofilm bacteria. J App Microbiol 1997, 83(4):477-484.

35. Rickard AH, Leach SA, Hall LS, Buswell CM, High NJ, Handley PS: Phylogenetic relationships and coaggregation ability of freshwater biofilm bacteria. App Environ Microbiol 2002, 68(7):3644-3650.

36. Kolenbrander PE, London J: Adhere today, here tomorrow: oral bacterial adherence. J Bacteriol 1993, 175(11):3247-3252.

37. Azevedo NF, Almeida C, Fernandes I, Cerqueira L, Dias S, Keevil CW, Vieira MJ: Survival of gastric and enterohepatic Helicobacter spp. in water: Implications for transmission. App Environ Microbiol 2008, 74(6):1805-1811.

38. Rickard AH, McBain AJ, Ledder RG, Handley PS, Gilbert P: Coaggregation between freshwater bacteria within biofilm and planktonic communities. FEMS Microbiol Lett 2003, 220(1):133-140.

39. Azevedo NF, Vieira MJ, Keevil CW: Development of peptide nucleic acid probes to detect $H$. pylori in diverse species potable water biofilms. In Biofilm communities: Order from chaos? Edited by: McBain A, Allison C, Brading M, Rickard A, Verran J, Walker J. Cardiff: Bioline; 2003:231-239.

40. Pernthaler A, Pernthaler J, Eilers H, Amann R: Growth Patterns of Two Marine Isolates: Adaptations to Substrate Patchiness? Appl Environ Microbiol 2001, 67(9):4077-4083.

41. Lehtola MJ, Torvinen E, Miettinen LT, Keevil CW: Fluorescence in situ hybridization using peptide nucleic acid probes for rapid detection of Mycobacterium avium subsp avium and Mycobacterium avium subsp paratuberculosis in potable water biofilms. App Environ Microbiol 2006 72(1):848-853.
42. Wilks SA, Keevil CW: Targeting species-specific low-affinity 16 S rRNA binding sites by using peptide nucleic acids for detection of legionellae in biofilms. App Environ Microbiol 2006, 72(8):5453-5462.

43. Rogers J, Dowsett AB, Dennis PJ, Lee JV, Keevil CW: Influence of plumbing materials on biofilm formation and growth of Legionella pneumophila in potable water systems. App Environ Microbiol 1994, 60(6):1842-1851.

44. Rogers J, Dowsett AB, Dennis PJ, Lee JV, Keevil CW: Influence of temperature and plumbing material selection on biofilm formation and growth of Legionella pneumophila in a model potable water system containing complex microbial flora. App Environ Microbiol 1994, 60(5):1585-1592

45. Ohno A, Kato N, Yamada K, Yamaguchi K: Factors influencing survival of Legionella pneumophila serotype 1 in hot spring water and tap water. App Environ Microbiol 2003, 69(5):2540-2547.

46. James BW, Mauchline WS, Dennis PJ, Keevil CW, Wait R: Poly-3hydroxybutyrate in Legionella pneumophila, an energy source for survival in low nutrient environments. App Environ Microbiol 1999, 65(2):822-827.

47. Murga R, Forster TS, Brown E, Pruckler JM, Fields BS, Donlan RM: Role of biofilms in the survival of Legionella pneumophila in a model potable water system. Microbiology 2001, 147:3121-3126.

48. Steinert M, Emody L, Amann R, Hacker J: Resuscitation of viable but nonculturable Legionella pneumophila Philadelphia JR32 by Acanthamoeba castellanii. App Environ Microbiol 1997, 63(5):2047-2053.

49. Wadowsky RM, Yee RB: Satellite growth of Legionella pneumophila with an environmental isolate of Flavobacterium breve. App Environ Microbiol 1983, 46(6):1447-1449.

50. James BW, Mauchline WS, Fitzgeorge RB, Dennis PJ, Keevil CW: Influence of iron limited continuous culture on physiology and virulence of Legionella pneumophila. Infect Immun 1995, 63(11):4224-4230.

51. Toze S, Sly LI, MacRae IC, Fuerst JA: Inhibition of growth of Legionella species by heterotrophic plate count bacteria isolated from chlorinated drinking water. Curr Microbiol 1990, 21(2):139-143.

52. Temmerman $\mathrm{R}$, Vervaeren $H$, Noseda B, Boon N, Verstraete W: Necrotrophic growth of Legionella pneumophila. App Environ Microbiol 2006 72(6):4323-4328.

53. Rogers J, Keevil CW: Immunogold and fluorescein immunolabeling of Legionella pneumophila within an aquatic biofilm visualized by using episcopic differential interference contrast microscopy. App Environ Microbiol 1992, 58(7):2326-2330.

54. Azevedo NF, Almeida C, Cerqueira L, Dias S, Keevil CW, Vieira MJ: Coccoid form of Helicobacter pylori as a morphological manifestation of cell adaptation to the environment. App Environ Microbiol 2007, 73(10):3423-3427.

55. Azevedo NF, Pinto AR, Reis NM, Vieira MJ, Keevil CW: Shear stress, temperature, and inoculation concentration influence the adhesion of water-stressed Helicobacter pylori to stainless steel 304 and polypropylene. App Environ Microbiol 2006, 72(4):2936-2941.

56. Mouery K, Rader BA, Gaynor EC, Guillemin K: The stringent response is required for Helicobacter pylori survival of stationary phase, exposure to acid, and aerobic shock. J Bacteriol 2006, 188(15):5494-5500.

57. Nilsson H-O, Blom J, Al-Soud WA, Ljungh A, Andersen LP, Wadstrom T: Effect of cold starvation, acid stress, and nutrients on metabolic activity of Helicobacter pylori. App Environ Microbiol 2002, 68(1):11-19.

58. West AP, Millar MR, Tompkins DS: Effect of physical environment on survival of Helicobacter pylori. J Clin Pathol 1992, 45(3):228-231.

59. Winiecka-Krusnell J, Wreiber K, Von Euler A, Engstrand L, Linder E: Freeliving amoebae promote growth and survival of Helicobacter pylori. Scand J Infect Dis 2002, 34(4):253-256.

60. Dailloux M, Laurain C, Weber M, Hartemann P: Water and nontuberculous mycobacteria. Water Res 1999, 33(10):2219-2228.

61. Fischeder R, Schulzerobbecke R, Weber A: Occurrence of mycobacteria in drinking water samples. Zentralblatt fur Hygiene und Umweltmedizin 1991 192(2):154-158.

62. Gião M, Wilks S, Azevedo N, Vieira M, Keevil C: Validation of SYTO 9/ Propidium lodide Uptake for Rapid Detection of Viable but Noncultivable Legionella pneumophila. Microb Ecol 2009, 58(1):56-62.

63. Gião MS, Azevedo NF, Wilks SA, Vieira MJ, Keevil CW: Effect of Chlorine on Incorporation of Helicobacter pylori into Drinking Water Biofilms. App Environ Microbiol 2010, 76(5):1669-1673. 
64. Keevil CW: Continuous culture models to study pathogens in biofilms. Method Enzymol 2001, 337:104-122.

65. Keevil CW: Rapid detection of biofilms and adherent pathogens using scanning confocal laser microscopy and episcopic differential interference contrast microscopy. Water Sci Technol 2003, 47(5):105-116.

66. Guimarães N, Azevedo NF, Figueiredo C, Keevil CW, Vieira MJ:

Development and application of a novel peptide nucleic acid probe for the specific detection of Helicobacter pylori in gastric biopsy specimens. J Clin Microbiol 2007, 45(9):3089-3094.

doi:10.1186/1471-2180-11-57

Cite this article as: Gião et al:: Interaction of legionella pneumophila and helicobacter pylori with bacterial species isolated from drinking water biofilms. BMC Microbiology 2011 11:57.

\section{Submit your next manuscript to BioMed Central} and take full advantage of:

- Convenient online submission

- Thorough peer review

- No space constraints or color figure charges

- Immediate publication on acceptance

- Inclusion in PubMed, CAS, Scopus and Google Scholar

- Research which is freely available for redistribution

Submit your manuscript at www.biomedcentral.com/submit
C Biomed Central 